\title{
Audit Market Concentration and Its Influence on Audit Quality
}

\author{
Patrick Velte $^{1} \&$ Markus Stiglbauer ${ }^{2}$ \\ ${ }^{1}$ School of Business, Economics and Social Sciences, University of Hamburg, Hamburg, Germany \\ ${ }^{2}$ School of Business and Economics, University of Erlangen-Nürnberg, Nuremberg, Germany \\ Correspondence: Markus Stiglbauer, Professor, School of Business and Economics, University of \\ Erlangen-Nürnberg, Lange Gasse 20, 90403 Nuremberg, Germany. Tel: 40-911-530-2108. E-mail: \\ markus.stiglbauer@wiso.uni-erlangen.de
}

Received: September 13, 2012

Accepted: September 25, 2012

Online Published: October 19, 2012

doi:10.5539/ibr.v5n11p146

URL: http://dx.doi.org/10.5539/ibr.v5n11p146

\begin{abstract}
This paper focuses on audit market concentration of listed firms which is characterized by an oligopoly of "Big Four" audit firms. Hence a state of the art analysis of the status quo of concentration measurement has been conducted on the audit market from an international perspective. Thereby risks and causes of concentration development have been assessed along with the current regulatory proposals of the European Commission (EC). After a discussion of conventional measurement methods of audit market concentration, our paper gives a review of previous empirical results of audit market concentration for EU and non EU-member states. Results show that EC reforms cannot clearly be related to increase audit quality but increasing transaction costs.
\end{abstract}

Keywords: audit market concentration, Big Four, audit quality, corporate governance, empirical audit research, audit regulation

JEL Classifications: G 34, M 42

\section{Introduction}

The audit market of publicly traded companies is highly concentrated in most European countries. The concentration of suppliers, characterized by the oligopoly of the so called "Big Four" audit firms (KPMG, PwC, Deloitte and Ernst \& Young), entails among others the fact that in the long term small- and medium-sized companies are forced out of the market. The term "concentration" describes the agglomeration of economic power, which is present in many industrial sectors, having diverse causes (Moeller \& Hoellbacher, 2009). Concentration development is subject of discussion in economic research since more than 150 years, whereas concentration evidence on the market of legally required audits for publicly traded companies, which is the focus of our analysis, is from an empirical point of view only established globally since the 1960's (Freidank \& Velte, 2012). The concentration of suppliers on the audit market, to be determined with the help of empirical studies, must be assessed negatively from the point of view of competition policy, since

- the incentives to ensure cost efficiency and appropriate audit quality are decreasing,

- higher barriers of entry for small and medium-sized audit firms exist and

- a strong influence from the Big Four on the development of international accounting- and audit standards (IFRS and ISA) must be assumed.

Along with increasing supplier concentration, the market power of big audit firms is increasing, so that, as a result of collective market dominance, price arrangements between the Big Four audit companies are possible in the course of cartelization. This concentration can possibly cause an oligopolistic or monopolistic market structure. However, the present competition intensity depends on many parameters and not only on the number of suppliers and their individual market shares (Helmenstein, 1996), so that the connection between audit market concentration and competition remains unclear. The EC has classified in their current audit regulation drafts of 2011 (EC, 2011a, 2011b) the increasing supplier concentration at the European audit market as a serious threat. The risks related to a potential discontinuation of one of the big audit companies are pointed out. It is particularly feared that a lasting loss of trust into the quality of external audit could occur, which is a considerable part of stability of the financial system.

With this in mind, the EC searches in their audit regulation draft of 2011 for possible opportunities to revive the audit market and face the market concentration. This article carries out a state of the art analysis of the status quo 
of concentration measurement on the audit market from an international perspective. The investigation is structured as follows: First, a theoretical foundation of audit market concentration followed by an analysis of causes of the concentration development is carried out (Section 2). Immediately following, the conventional measurement methods of audit market concentration are presented (Section 3) before the focus lies on the empirical review of previous results of audit research for several EU-member states and non-member states (Section 4). A critical conclusion along with future prospects completes the analysis (Section 5).

\section{Theoretical Foundation and Causes of Audit Market Concentration}

\subsection{Theoretical Foundation}

"There are a number of reasons why stakeholders are concerned about the current market structure for the supply of audit services to public interest corporations" (Oxera, 2007, 190). This might cause "monopolistic pricing, a decline in the quality of audits and of the services provided by audit firms, a decrease in the stability of capital markets and in investor confidence, and the impact of another large public accounting firm failure" (Cammack \& Caban-Garcia, 2005, 3). Furthermore, different reports have analyzed the impact of audit market concentration on an international level (Francis et al., 2011), e.g. the EC's "Green Paper" on "Audit Policy: Lessons from the Crisis", the report "Auditors: Market concentration and their role" from the House of Lords in the UK or the United States General Accounting Office's reports on "Public Accounting Firms: Mandated Study on Consolidation and Competition" and "Audits of Public Companies: Continued Concentration in Audit Market for Large Public Companies Does Not Call for Immediate Action" (House of Lords, 2011; European Commission, 2010; United States General Accounting Office, 2003; United States General Accounting Office, 2008). Over the past 25 years the audit market has undergone a development towards strong concentration (Figure 1).

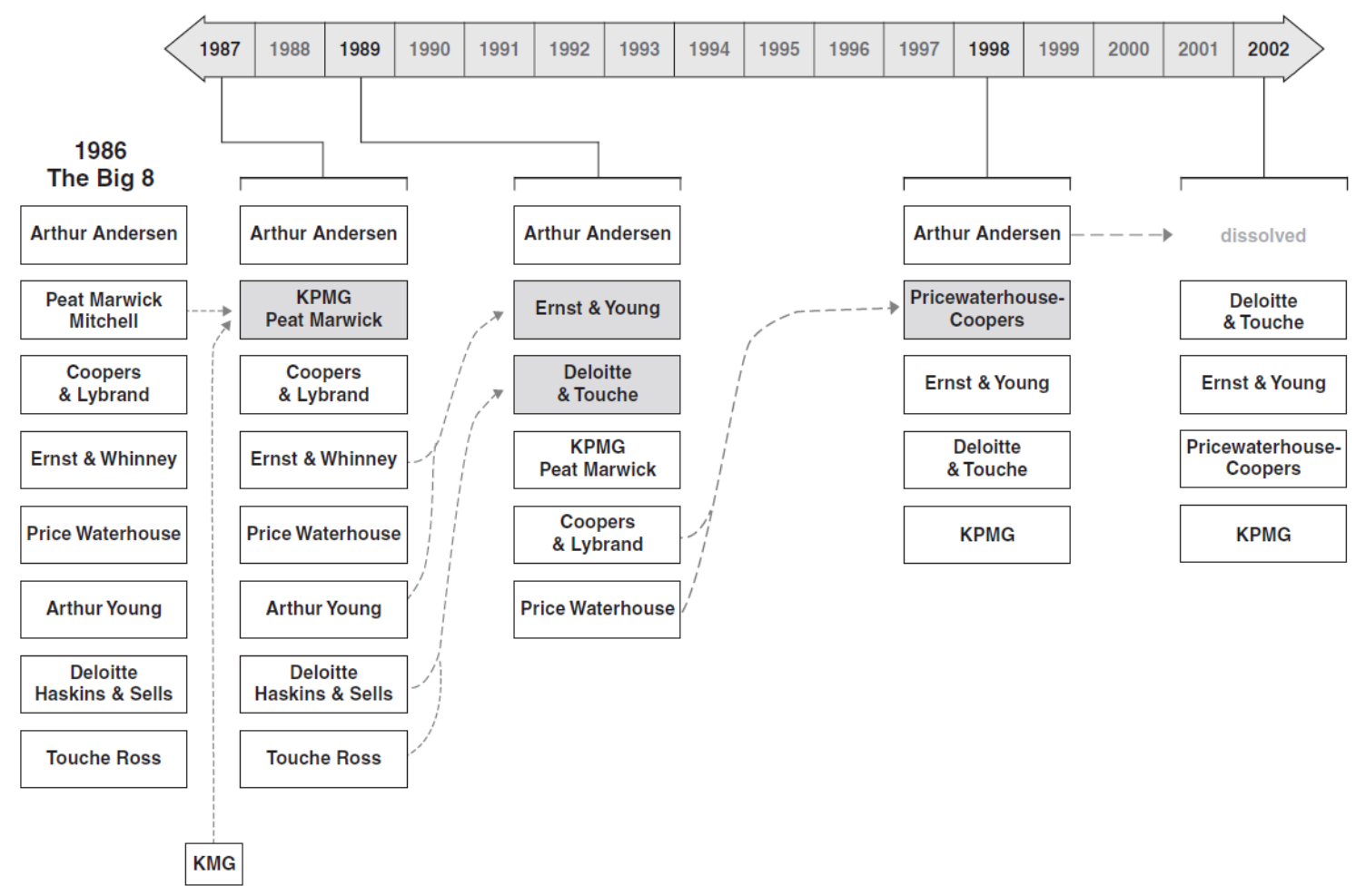

Figure 1. 1980s and 1990s: Significant mergers in the audit market

Source: United States Government Accountability Office, 2008, 9.

The competitive situation at the audit market and the tendencies towards supplier concentration can be consolidated by numerous approaches used in industrial economics (Hachmeister, 2001). Here, explanations are searched for how the number of market players and their competitive interaction along with market imperfections, generated by offering heterogeneous products and services, and market entry barriers or asymmetric information influences the market behavior and the market structure. According to the structure conduct performance-paradigm, the market structure is, following the traditional version, determined by 
exogenous factors. Here, the industrial and competitive analysis by Porter (2008) is granted outstanding significance. The structure of the audit market is thus an essential factor of competitiveness for audit companies. According to Porter (2008), the market concentration can be interpreted as a strategic competitive advantage of an enterprise, provided that a higher additional benefit for the client is offered. This additional benefit of a basic product or service can be reducible to a lower bid price or an additional service with appropriate surcharge. In the recent past, the structure conduct performance-theory experienced a considerable advancement through the endogenization of cause variables of market structure. Hereby, among others, the game theory is important, which analyses the competitive interactions and effects of asymmetric information distribution and therefore considers interdependencies between market structure and market behavior. Within the scope of the transaction cost theory efforts are made to bring into focus the structures of authority and surveillance in companies and to clarify possible coordination problems. Last but not least, an economic analysis of the influence of legal environment on the market structure and market behavior is just as important.

DeAngelo (1981) has first applied the size of an audit company as a surrogate for audit quality. According to that, big audit firms - measured by the number of clients - tend to be more independent of one specific client than medium-sized companies, which, as the case may be, have only few and for the total volume relevant clients and therefore could pursue incentives to satisfy the wishes of management to approve unrestrictedly, even when accounting errors were found (Marten, 1999). DeAngelo (1981) explains her assessment with the existence of quasi-rents. The original inspection causes start up costs on the auditor and transaction cost on the client, which develops a bilateral monopoly. In a bilateral monopoly, both contracting parties are interested in a long-term perpetuation of their relations. From an auditor's point of view, a change of auditor would lead to a loss of client-specific quasi-rents, the companies to be audited would have to incur additional searching cost finding a new qualified auditor. Since big audit firms have more mandates than medium-sized firms and therefore a higher diversification of risk, according to DeAngelo (1981) the probability increases that the auditor reports correctly about accounting errors and balance sheet manipulation. The impending loss of quasi-rents of a client can easier be cushioned by other mandates on the lines of cross-subsidization and tends to lead to a lower financial dependency relating to one mandate. Especially the impending loss of reputation plays an important role for big audit firms, if capital markets assume a decreasing audit quality. Through this, not only the mandate in question could go astray, but additional ones on other national and international audit markets. Insofar, with increasing size of the audit firm, independence and demand increases as well from a capital market's point of view. As positive influence on trust building on the capital market can be the result of commissioning one of the big audit firms, management follows the trend and assigns preferably one of the Big Four.

As a follow-up study, Palmrose (1986) investigated the connection between audit firm size and audit fee. Hereby, it is assumed, that big audit firms demand a markup when owning a market position approaching that of a monopoly, in order to signalize higher audit quality. These hypotheses are contrary to low balling, after which audit firms agree with the client upon a not cost-covering audit fee in the first audit period hoping this would lead to future rationalization effects. Consequently, it is examined in addition whether the existence of economies of scale entails lower audit fees of audit companies in comparison to competition. Palmrose (1986) could prove that the "Big Eight" invoiced higher audit fees (price premium). This was said to be attributable to the higher audit quality or the monopolistic structures on the audit market. Besides, it could be confirmed that the Big Eight spend relatively more hours of work on a mandate comparable in scale.

\subsection{Causes of Audit Market Concentration}

The internationalization of financial accounting and audit along with the increasing number of mergers induced the fact that the audit market for capital market-oriented companies is served incrementally by big audit firms in Europe. The cause of this development is the search of globally acting enterprises for an auditor, who offers services on a comparable standard in the respective state of a subsidiary. The choice for one of the big audit firms is associated in literature with enhanced audit quality and reputation, with which in case of trust reinforcement on the capital market the firm value can be influenced positively (Rama \& Read, 2006). Besides, the more stringent demands in terms of performing the audit of annual accounts, which are associated with compliance of IFRS and ISA along with the increasing regulatory obligation to report, can be accompanied by higher fixed cost and be decisive for supplier concentration (Quick \& Sattler, 2011). From an European point of view, especially the 8th EC directive of 2006 is important which influences crucially the requirements in structural and procedural organization. Other causes for consolidation at the audit market are the involuntary retirement of audit firms, in- and external growth (mergers), the product differentiation being dominant in big audit companies, reputation building along with the investors' wish for a prompt publication of certified accounting (fast close). 


\section{Concentration Measures}

The measure of audit market concentration in previous empirical studies is characterized by heterogeneity. Using absolute (relative) concentration variables, the number (share) of certain audit companies on the whole market volume is considered. As absolute measures, the concentration rate (CR) and the Herfindahl-Hirschmann Index (HHI) are to be distinguished, while the Gini-coefficient $(\mathrm{G})$ and the Lorenz curve are to be mentioned as relative measures (Quick \& Sattler, 2011). The CR-value covers the proportion of the $\mathrm{m}$ biggest audit firms within a sample. With this respect the market shares of the $\mathrm{m}$ biggest audit firms within a sample were cumulated to a CR-value $\left(\mathrm{CR}(\mathrm{m})=\sum(\mathrm{xi} / \mathrm{x})\right)$. An oligopoly is present, if at most three audit companies have a market share of $>50 \%$ or at least five companies have a market share of $>66.6 \%$ respectively. A monopoly position is assumed, if an audit firm has more than one third of total market share. CR is easily to be calculated and to be interpreted. Those companies, which are smaller than the m biggest firms are not included in the calculation. With this in mind, literature points to the HHI instead. The HHI has an advantage against the concentration rate since it covers all audit firms on a specific market. The HHI is calculated by summing up the square value of the market share of each audit firm against the overall market $\left(\mathrm{HHI}(\mathrm{m})=\sum(\mathrm{xi} / \mathrm{x})^{2}\right)$. The following forms of $\mathrm{HHI}$ can be distinguished:

- a complete concentration is indicated with $\mathrm{HHI}=1$,

- in case of minimal concentration an equal share $1 / \mathrm{n}$ is allocated to each carrier (n),

- an unconcentrated market is assumed to exist if the value of $\mathrm{HHI}<0.10$ and a highly concentrated market is assumed to be present at a value of $\mathrm{HHI}<0.18$.

The reciprocal value of HHI is called Numbers Equivalent (NE) and is used partly in addition to other concentration measures in empirical studies. It specifies the number of audit firms with equal market share that correspond to a concrete market situation. To give an example, an $\mathrm{HHI}=0.2$ makes a situation palpable in which the entire audit market is equally divided up between five audit firms. The Lorenz curve as a relative measure variable (disparities) is not a concentration measure in a narrower sense it merely represents the frequency distribution in graphic form.

The deviation of resulting Lorenz curve fundamentally a monotonic increasing convex function of straight uniform distribution (diagonal) results in the concentration (Marten \& Schultze, 1998). The more the Lorenz curve deviates downwards from the diagonal the more supplier concentration is increasing. The use of the Lorenz curve cannot be recommended for markets with only few company units, since for instance the existence of only two companies of same size indicates a concentration level of zero. Therefore, the Lorenz curve is suited for market share analysis of big audit firms only as a complement to other concentration measures (Grothe, 2005). After all, the relative concentration measure $G$ indicates mathematically the area between Lorenz curve and straight uniform distribution relative to the triangular area underneath the half diagonal. The relative concentration therefore is the result of deviation from property values from a hypothetical uniform distribution of carriers:

- in case of a complete uniform distribution, $\mathrm{G}$ assumes the value of 0 ,

- in case of perfect concentration, the value comes close to 1 ,

- with $\mathrm{G}>0.9$ a very high concentration can be assumed,

- with $\mathrm{G}>0.6$ and $<=0.9$ high concentration exists,

- market concentration is moderate if $\mathrm{G}$ is between 0.4 and 0.6.

Insofar, the choice of one or more of the different concentration measures depends on the respective goal of the study. In light of limited force of expression of one isolated factor based on possible bias, the use of several or all concentration measures is appropriate. Relevant are not only absolute but also relative measures, since the number and size of audit companies as well as the firms' differences in market share are within focus for further analysis.

\section{Review of Audit Market Concentration Research}

\subsection{Fundamentals}

Concentration measurements for the audit market are recently the focus in empirical audit research from a national and international point of view. Studies are targeted at the analysis of market changes and effects on the competitive conditions for audit firms. By the potentially collective market dominance of big audit companies reduced competition can be evaluated based upon, among other factors, change of auditors' quota and the extent 
of audit fees. Hereby, statistical considerations that choose a certain accounting year, and dynamic considerations that make chronological comparisons can be differentiated.

From a US-American point of view, concentration is often measured based on audit fees, while studies about the German audit market traditionally calculate approximately the market share with the help of the mandate numbers, balance sheet total and/or sales revenues of clients, since the publication of fees has only been obligatory since 2005. Insofar, there is only indirect connection to real audit fees. The assumption here is that audit fees have a positive association with balance sheet total and sales revenues. However, instead of a linear connection, a digressive correlation is assumed, whereupon the audits or rather the scope of audit fees increases in steady smaller growth rates along with an increase in company-size (Pong \& Whittington, 1994). Even though with an increase in firm size the number of audit areas increases as well, an additional need for audit can be balanced out at least in parts primarily with the help of

- an audit approach oriented towards business risk (business risk audit),

- the review of risk management systems,

- the extension of analytical audits or,

- the greater use of sampling inspection,

so that a disproportionately low increase of audit fees becomes likely (Quick et al., 1998). Consequently, instead of the untransformed factors, the square root of balance sheet total or the square root of sales revenues is to be used. While the untransformed factors tend to overvalue concentration, transformed variables undervalue the concentration development. In empirical studies both factors are used as corridor values or rather intervals (Quick et al., 1998). The measurement of concentration based on client numbers is insufficient and only allowed as an auxiliary variable. Even though, numerous concentration measurements have been conducted recently from an European point of view, state of the art reviews tend to be found rarely, which summarize transnationally the respective results of empirical audit research concerning supplier concentration. While there is no review in German literature, Yardley et al. (1992) have analyzed the results of research on the US American audit market until the end of 1980's. In contrast, Walker \& Johnson (1996) presented selected concentration studies on Australia, UK, New Zealand and Denmark. Insofar, an increasing need for research accrues in light of the EC regulation draft of 2011, which relates the increasing supplier concentration at the European audit market to a decrease in audit quality. Herewith, an increase in supplier concentration with essential impact on competitiveness of audit firms, the amount of audit fees as well as auditor independence is said to be associated. Resulting from the mergers of audit firms and the internationalization of accounting and auditing the supplier concentration is recognized as a global phenomenon (Gilling \& Stanton, 1978), so that in the following the German audit market is included first, followed by other EU member states and Switzerland as a non-EU-member state. An enhanced research density is allocated to UK with regard to EU-member states. A transnational comparison of past studies is only possible within the scope of diverging assessment periods and objects as well as sample sizes, deviating legal systems and national accounting and auditing standards (Grothe, 2005).

\subsection{EU-member States}

\subsubsection{Germany}

The last studies which deal exclusively with surrogates of market shares are Huellweck and Ostrowski, Strickmann, Lenz and Bauer and Grothe. The study of Huellweck and Ostrowski (2000) demonstrated high ratios of concentration for 1996 and 1997 [CR4 = 0.84 (1997)] and can be confirmed by Strickmann (2000) for 1989, 1993 and 1997 [CR 4 = 0.73 (1997)]. Thereafter approaches of a monopoly of the Big Four audit firms can be identified in some industries. Bauer (2004) and Lenz and Bauer (2004) observed for 2002 a concentration ratio of CR4 $=0.86$ which exceeds the results of the previous study by Huellweck and Ostrowski (2002). Moreover coherence between the stock index and the selection of a Big Four is derived. While PwC is identified as the market leader in the DAX and TecDAX, KPMG dominates the MDAX. However, balanced market shares can be found in the DAX. Likewise, Grothe (2005) proved an increasing concentration development on the German audit market for 1996, 1998 and 2000 [CR4 = 0.79 (2000)]. However, during the study period no trend towards homogenization of the market shares within the oligopoly group during the study period is evident.

Just since 2005, the declaration of the (non) audit fees in the notes is mandatory in Germany. Moreover, audit firms which conduct audits for at minimum one public interest company, must state the (non) audit fees in a transparency report. Because of these disclosure reforms, current studies which include now directly the audit fees in the empirical research have a higher significance. According to Zimmermann (2008) and Bigus and 
Zimmermann (2008) who examine the fiscal year 2005, the Big Four audit firms, under the market leadership of PwC, collect $87 \%$ of the audit fees resp. $90 \%$ of the total fees. Further, the consulting stake amounts to $41.9 \%$ of the final audit, which is higher than in the study by Lenz, Moeller and Hoehn (2006) (34\%). The concentration ratio $(\mathrm{CR} 4=0.85)$ is higher than the ratio in Switzerland and lower than in comparatistics from the USA and the UK. The fees for audits and services close to audits are, according to Bigus and Zimmermann (2008), 7.3\% higher for SEC-issuers than for not SEC-quoted companies. Based on the one-periodic snapshot, the significance of these studies is limited.

In contrast, the empirical studies by Moeller and Hoellbacher, Koehler et al., Sattler and Quick and Sattler are more important as they undertake time series analysis. Moeller and Hoellbacher (2009) examine a long time series (1997-2007) and conduct concentration measurements through the use of direct and indirect variables (audit fee, total balance sheet, sales revenue and number of mandates). Very high concentration measurement on the German audit market can be derived for the last reporting interval 2007 (CR4 =0.97). KPMG and PwC have an average market share of $52 \%$ (audit assignment) resp. $86 \%$ (total balance sheet). Besides a slight increase for the concentration ratio over time can be determined. Koehler et al. (2010), Sattler (2011) and Quick and Sattler (2011) examined the time period 2005-2007 and confirmed the results of Moeller and Hoellbacher (2009). Koehler et al. (2010) proved a clear dominance of the Big Four [cumulative market share of $93 \%$ of the audit fees; CR4 = 0.93 (2007)]. Sattler (2011) and Quick and Sattler (2011) slightly lower concentration ratios [CR4 = 0.83 (2007)].

Since the first measurements, an overview manifests a high provider concentration on the German audit market and increasing development over the period of time as a permanent phenomenon, even for the last examined year 2007. On the German audit market, the supplier concentration can be classified as an oligopoly of the Big Four, where in certain industries or market segments even monopoly resp. duopoly structures are recognizable (Bigus \& Zimmermann, 2008). However, the hypothesis, raised by the EC, that a high concentration is stringent related with restraints of competition, cannot be empirically confirmed. Rather, even in duo- or monopolistic market structures a high level of competition is possible. Indications on this can also be found in Germany, e.g. by increasing calls for tender of audit orders and aggressive marketing efforts of audit firms (Heer, 2001). Nevertheless the validity of the studies is limited, if only single years instead of time-series analyses are considered. Throughout the cited empirical examinations high resp. very high concentration results can be obtained. From a descriptive point of view it must be noted that KPMG and PwC (formerly C\&L) have for many years the market leadership, while Deloitte and Ernst and Young, achieve much less market shares. In the cited studies, the market position of BDO as the largest non-Big Four company in Germany is classified as rather low (Quick \& Sattler, 2011).

\subsubsection{United Kingdom}

Similar to the German audit market high rates for supplier concentration are derived in UK. In contrast to the German studies, the use of the Lorenz curve and G-coefficients for the exposition of the concentration development is omitted. Rather, CR and HHI are focused. A high density of research can be found for the UK audit market. The study of Briston and Kedslie (1985) includes a long time series analysis from 1928 to 1984. Here, a rise in the market share of the Big Eight from 28.7\% to $46.2 \%$ between 1968 and 1978 can be observed. In 1984, CR4 is with 0.38, quite moderate. Subsequent to this, Moizer and Turley (1989) show for 1972 and 1982 the structural changes in the British audit market. Since the Companies Act 1967, UK has a disclosure requirement for the audit fees which can be used directly to measure market concentration. An increasing concentration can be determined for the study period (from 0.47 to 0.54 ). In addition, a significant reduction of audit firms from 144 to 85 companies can be assessed. As reasons for this development, the mergers of audit firms, the replacement of audit firms and the dwindling of joint audits are named. Moreover, a positive correlation between audit fees and supplier concentration can be found. Beattie and Fearnley (1994) state that the market shares for the Big Six is $72 \%$ in 1991. The increasing concentration process over time [from CR $4=0.43$ (1987) to 0.59 (1991)] can be explained with mergers of larger audit firms and auditor changes, whereby the large audit firms must pass comparatively less mandates to smaller audit firms. As one of just few studies, Pearson and Trompeter (1994) found for the years 1982-86 a negative correlation between supplier concentration and audit fees. The merger effects within the Big Eight on the audit fees are also in the focus by Iyer and Iyer (1996) for 1987-91, which found no substantial evidence for a relationship between concentration and audit fees. However, the increasing ratios of concentration over time (from CR4 $=0.45$ to 0.57 ) can be justified analogical to previous studies of mergers of audit firms. Since the focus is solely on the 20 market leaders of audit firms for the period before and after the mergers, the validity is due to distorted findings (bias problem) limited. These results are, as already shown, in opposition to Pearson and Trompeter (1994). Peel (1997) can distinguish 
essential segment-specific differences for 1995 for the market shares within the Big Six (CR6 amounts to 0.78). Pong (1999) states only a slight increase in the concentration (from CR4 $=0.57$ to 0.6) for 1991-95, since no mergers occur between firms in this period. The UK audit market is characterized as an oligopoly.

Also the Big Four consolidation due to the elimination of Arthur Andersen has a major influence on the market concentration in UK. Beattie, Goodacre and Fearnley (2003) examine that the Big Four have a market share of $90 \%(96 \%)$ in the period before (after) the collapse of Arthur Andersen in 2002. PwC is the market leader with $37 \%$ of all audit engagements. The Big Four concentration increases from 0.67 (2002) to 0.73 (2003). Also Pong and Burnett (2006) found an increase in $2001(\mathrm{CR} 4=0.64)$ compared to $1997(0.61)$. McMeeking, Peasnell and Pope (2007) prove a positive correlation between concentration and audit fees as well as between concentration and mergers of audit firms. The increase in the concentration ratios from CR4 $=0.65$ (1985) to 0.83 (2002) is above average. Abidin, Beattie and Goodacre (2010) also determine for 1998-2003 an increasing concentration over time based on audit fees [CR4 $=0.88$ (1998) and 0.96 (2003)], whereby the concentration ratio remains approximately constant on the basis of audit engagements. The omission of Arthur Andersen also leads to a greater balancing of the market share among the major audit firms.

\subsubsection{Belgium}

Also in other EU-member states like Belgium, the Netherlands, Denmark, Sweden and Spain, audit market concentration studies are increasingly conducted. Regarding the selection of variables for the measurement of the market share a high heterogeneity can be observed, although, in general the studies resort to only one variable.

For the Belgian audit market, Schaen and Maijoor (1997) can determine a positive correlation between the concentration ratios for the entire sample and the industry-specific concentration ratios for 1987. Not surprisingly, industry-specific differences for the concentration ratios in the range of CR $4=0.22$ to 0.78 can be found. According to Weets and Jegers (1997), the Belgian audit market show in comparison to other EU industrial member states lower concentration ratios for 1989 to 1995 , wherein an rising trend from CR4 $=0.41$ (1989) to 0.56 (1995) can be assessed. In an update of Willekens and Akhmadi (2003) for 1989 and 1997, a positive correlation between the market share of the audit firm and the audit fee is demonstrated, whence the authors derive an increased price competition.

\subsubsection{The Netherlands}

One of the longest international time series analysis stems from Maijoor et al. (1995), which covers the period from 1880 to 1990 in the Dutch audit market. First since 1970, a significant increase in concentration can be determined which is explained by growing regulatory standards and mergers. However, until the 1960s, very low and constant concentration ratios can be assessed for the Dutch audit market. Buijink, Maijoor and Meuwissen (1998), who put the years 1970 to 1994 as a basis, can identify a substantial increase of provider concentration between 1970-1973 and 1988-1991. Analogous to other international comparative studies, the mergers between audit firms is stated as a reason for the results. In a country comparison with Germany (CR4 $=0.16)$, the concentration ratios are significantly higher $(\mathrm{CR} 4=0.52)$.

\subsubsection{Scandinavia}

Based on 1983, 1989 and 1990, a significant increase in the concentration ratios [CR4 $=0.543$ (1989) and 0.705 (1990)] on the Danish audit market can be verified by Christiansen and Loft (1992) which is primarily explained with mergers. However, between 1983 and 1989 only minor deviations can be detected. The audit market is classified as a duopoly. According to Loft and Sjoefors (1993) an essential increase in the concentration ratios for 1983 and 1990 (Denmark) resp. 1985 and 1990 (Sweden) can be stated as well, whereby a dominance of two (Denmark) resp. three (Sweden) audit firms exist.

\subsubsection{Spain}

Spain entered the EU in 1986 and as a result the statutory audit requirements based on the 8th EC Directive began just in the end of the 1980s. Therefore the empirical audit research is in comparison to other named EU-countries of younger history. The first and only country-specific study of Romero et al. (1995) can determine a clear increase in the concentration for 250 companies in the period 1991-93. Since the implementation of the audit requirements, the dominance of the Big Six can be assessed. Their market share grows between the years $1991-93$ from $83 \%$ to $95 \%$.

Table 1 gives a summary of the results of the empirical concentration studies in the EU-member states. 
Table 1. Empirical research on audit markt concentration in EU member states

\begin{tabular}{|c|c|c|c|c|c|}
\hline Country & $\begin{array}{l}\text { Author(s) } \\
\text { and Year of } \\
\text { publication }\end{array}$ & $\begin{array}{l}\text { Sample } \\
\text { Observation } \\
\text { period }\end{array}$ & $\begin{array}{l}\text { Method of } \\
\text { concentration } \\
\text { measurement } \\
\end{array}$ & $\begin{array}{l}\text { Variables for measurement } \\
\text { of market share }\end{array}$ & Main results \\
\hline \multirow[t]{8}{*}{ Germany } & $\begin{array}{l}\text { Huellweck \& } \\
\text { Ostrowski } \\
(2000)\end{array}$ & $\begin{array}{l}\mathrm{n}=586 \text { and } 605 \\
1996-1997\end{array}$ & $\begin{array}{l}\text { CR2, CR6-7, } \\
\text { HHI } \\
\text { G }\end{array}$ & $\begin{array}{l}\text { Number of audit assignments } \\
\text { Total assets (absolute and } \\
\text { square root) }\end{array}$ & $\begin{array}{l}\text { Changes of auditors only } 6.2 \% \\
\text { Significant loss of mandates at C\&L }\end{array}$ \\
\hline & $\begin{array}{l}\text { Strickmann } \\
(2000)\end{array}$ & $\begin{array}{l}\mathrm{n}=1,142 \\
1989,1993 \text { and } \\
1997\end{array}$ & $\begin{array}{l}\text { CR2-4, CR6-7 } \\
\text { HHI, NE, G and } \\
\text { Lorenz curve }\end{array}$ & $\begin{array}{l}\text { Number of audit assignments } \\
\text { Estimated Audit Fees } \\
\text { Total assets (standardized) } \\
\text { (absolute and square root) }\end{array}$ & $\begin{array}{l}\text { High concentration and increase in observation period } \\
\text { Formation of oligopoly, tending towards duopoly } \\
\text { Weak form of monopoly position in some industries }\end{array}$ \\
\hline & $\begin{array}{l}\text { Bauer (2004) } \\
\text { Lenz \& } \\
\text { Bauer (2004) }\end{array}$ & $\begin{array}{l}\mathrm{n}=133 \\
2001-2002\end{array}$ & - & $\begin{array}{l}\text { Number of mandates } \\
\text { Total assets (absolute and } \\
\text { square root) }\end{array}$ & $\begin{array}{l}\text { Correlation between stock exchange index and the } \\
\text { selection of a Big Four audit firm } \\
\text { PwC Market leader in DAX and TecDAX } \\
\text { MDAX dominated by KPMG; } \\
\text { Market shares in SDAX balanced }\end{array}$ \\
\hline & $\begin{array}{l}\text { Grothe } \\
(2005)\end{array}$ & $\begin{array}{l}\mathrm{n}=2,315 \\
1996,1998 \text { and } \\
2000\end{array}$ & CR2-7, HHI, G & $\begin{array}{l}\text { Number of audit assignments } \\
\text { Total assets (standardized) } \\
\text { (absolute and square root) }\end{array}$ & $\begin{array}{l}\text { Oligopolistic market structure with high degree of } \\
\text { concentration } \\
\text { No tendency towards homogenization of market } \\
\text { shares within the oligopoly group during observation } \\
\text { period }\end{array}$ \\
\hline & $\begin{array}{l}\text { Zimmermann } \\
(2008) \\
\text { Bigus \& } \\
\text { Zimmermann } \\
(2008)\end{array}$ & $\begin{array}{l}n=167 \\
2005\end{array}$ & $\begin{array}{l}\text { CR2, } \quad \text { CR4, } \\
\text { CR6, HHI, G }\end{array}$ & $\begin{array}{l}\text { Total fee } \\
\text { Audit fee } \\
\text { Total assets (absolute and } \\
\text { square root) } \\
\text { Sales revenues (absolute and } \\
\text { square root) }\end{array}$ & $\begin{array}{l}\text { High concentration } \\
\text { Big Four hold a market share of } 90 \%\end{array}$ \\
\hline & $\begin{array}{l}\text { Moeller \& } \\
\text { Hoellbacher } \\
(2009)\end{array}$ & $\begin{array}{l}\mathrm{n}=100,199 \\
200,198,197 \\
150,159,160 \\
160,160 \\
1997-2007\end{array}$ & $\begin{array}{l}\text { CR1-5, HHI, } \\
\text { NE, G }\end{array}$ & $\begin{array}{l}\text { Number of audit assignments } \\
\text { Total assets (absolute and } \\
\text { square root) } \\
\text { Sales revenues (absolute and } \\
\text { square root) } \\
\text { Audit fee }\end{array}$ & $\begin{array}{l}\text { High concentration } \\
\text { KPMG and PwC hold an average market share of } 52 \% \\
\text { (assignments) and } 86 \% \text { (total assets) respectively } \\
\text { Slight increase of concentration rates over time }\end{array}$ \\
\hline & $\begin{array}{l}\text { Koehler et al. } \\
(2010)\end{array}$ & $\begin{array}{l}n=1,341 \\
2005-2007\end{array}$ & CR2, CR4, CR7 & $\begin{array}{l}\text { Audit fee } \\
\text { Total assets (absolute and } \\
\text { square root) } \\
\text { Sales revenues (absolute and } \\
\text { square root) }\end{array}$ & $\begin{array}{l}\text { Slight increase of concentration rates and increasing } \\
\text { dominance of Big Four (from } 88.39 \% \text { to } 92.95 \% \text { ) } \\
\text { Tendency towards duopoly formation }\end{array}$ \\
\hline & $\begin{array}{l}\text { Sattler (2011) } \\
\text { Quick \& } \\
\text { Sattler (2011) }\end{array}$ & $\begin{array}{l}n=435 \\
2005-2007\end{array}$ & $\begin{array}{l}\text { CR4, HHI, G } \\
\text { and Lorenz } \\
\text { curve }\end{array}$ & $\begin{array}{l}\text { Number of audit assignments } \\
\text { Audit fee }\end{array}$ & $\begin{array}{l}\text { Oligopoly position } \\
\text { Dominance of Big Four primarily in DAX } \\
\text { Increasing concentration over time }\end{array}$ \\
\hline \multirow[t]{3}{*}{ Belgium } & $\begin{array}{l}\text { Schaen \& } \\
\text { Maijoor } \\
(1997)\end{array}$ & $\begin{array}{l}\mathrm{n}=10,692 \\
1987\end{array}$ & CR4, CR8, HHI & Sales revenues (Square root) & $\begin{array}{l}\text { High heterogenity in industry-related concentration } \\
\text { rates }(\mathrm{CR} 4=0.22-0.78) \\
\text { Positive correlation between total and industry-related } \\
\text { concentration }\end{array}$ \\
\hline & $\begin{array}{l}\text { Weets } \quad \& \\
\text { Jegers }(1997)\end{array}$ & $\begin{array}{l}\mathrm{n}=129,136 \\
147,165,170 \\
\text { and } 180 \\
1989-1995\end{array}$ & $\begin{array}{l}\text { CR4, CR6, } \\
\text { CR8, HHI }\end{array}$ & $\begin{array}{l}\text { Number of audit assignments } \\
\text { per establishment } \\
\text { Number of Audit } \\
\text { assignments } \\
\text { Sales revenues }\end{array}$ & $\begin{array}{l}\text { Lower concentration rates compared to other EU } \\
\text { industrial countries } \\
\text { Increasing concentration over time from CR4 }=0.41 \\
\text { (1989) to } 0.56(1995)\end{array}$ \\
\hline & $\begin{array}{l}\text { Willekens \& } \\
\text { Achmadi } \\
(2003)\end{array}$ & $\begin{array}{l}\mathrm{n}=48 \text { and } 71 \\
1989 \text { and } 1997\end{array}$ & $\begin{array}{l}\text { CR4, CR6, } \\
\text { CR8, HHI }\end{array}$ & $\begin{array}{l}\text { Personel costs } \\
\text { Number of audit assignments } \\
\text { per establishment }\end{array}$ & $\begin{array}{l}\text { Positive correlation between market share of Audit } \\
\text { firms and Audit fees (increased price competition) } \\
\text { Significant Increase of concentration from CR } 4=0.47 \\
\text { (1989) to } 0.62 \text { (1997), though lower rates than in other } \\
\text { EU industrial countries }\end{array}$ \\
\hline Denmark & $\begin{array}{l}\text { Christiansen } \\
\& \quad \text { Loft } \\
(1992)\end{array}$ & $\begin{array}{l}\mathrm{n}=250 \\
1983,1989 \text { and } \\
1990\end{array}$ & $\begin{array}{l}\text { CR4, } \\
\text { CR15, }\end{array}$ & $\begin{array}{l}\text { Sales revenues (absolute and } \\
\text { square root) }\end{array}$ & $\begin{array}{l}\text { Increase of concentration compared to other countries } \\
\text { (from CR4 }=0.5(1983) \text { to } 0.7(1990) \text { ) } \\
\text { Audit market classified as duopoly }\end{array}$ \\
\hline $\begin{array}{l}\text { Denmark/ } \\
\text { Sweden }\end{array}$ & $\begin{array}{l}\text { Loft } \quad \& \\
\text { Sjoefors } \\
(1993)\end{array}$ & $\begin{array}{l}\mathrm{n} \quad=\quad 185 \\
\text { (Sweden) and } \\
250 \text { (Denmark) } \\
1985 / 1990 \\
\text { (Sweden) } \\
1983 / 1990 \\
\text { (Denmark) }\end{array}$ & $\begin{array}{l}\text { CR4, } \\
\text { CR15, }\end{array}$ & $\begin{array}{l}\text { Sales revenues (absolute and } \\
\text { square root) }\end{array}$ & $\begin{array}{l}\text { Significant increase of concentration } \\
\text { Dominance of two (Denmark) or three (Sweden) audit } \\
\text { firms respectively }\end{array}$ \\
\hline
\end{tabular}




\begin{tabular}{|c|c|c|c|c|c|}
\hline Country & $\begin{array}{l}\text { Author(s) } \\
\text { and Year of } \\
\text { publication }\end{array}$ & $\begin{array}{l}\text { Sample } \\
\text { Observation } \\
\text { period }\end{array}$ & $\begin{array}{l}\text { Method of } \\
\text { concentration } \\
\text { measurement }\end{array}$ & $\begin{array}{l}\text { Variables for measurement } \\
\text { of market share }\end{array}$ & Main results \\
\hline France & Piot (2005) & $\begin{array}{l}\mathrm{n}=285 \\
1997\end{array}$ & $\begin{array}{l}\text { CR3, } \\
\text { CR6, CR8, } \mathrm{HHI}\end{array}$ & $\begin{array}{l}\text { Number of audit assignments } \\
\text { Sales revenues }\end{array}$ & High concentration of $\mathrm{CR} 4=0.58$ \\
\hline \multirow[t]{11}{*}{ UK } & $\begin{array}{l}\text { Briston \& } \quad \& \\
\text { Kedslie } \\
(1985)\end{array}$ & $\begin{array}{l}\text { n.s. } \\
1928-1984\end{array}$ & CR1-CR20 & Number of audit assignments & $\begin{array}{l}\text { Growing market share of Big Eight from } 28.7 \% \text { to } \\
46.2 \% \text { between } 1968 \text { and } 1978 \\
\text { CR4 }=0,38(1984)\end{array}$ \\
\hline & $\begin{array}{l}\text { Moizer \& } \\
\text { Turley }(1989)\end{array}$ & $\begin{array}{l}\mathrm{n}=498 \\
1972 \text { and } 1982\end{array}$ & $\begin{array}{l}\text { CR4, CR9, } \\
\text { CR16, HHI }\end{array}$ & $\begin{array}{l}\text { Number of audit assignments } \\
\text { Audit fees }\end{array}$ & $\begin{array}{l}\text { Increase of both concentration (from CR } 4=0.47 \text { to } \\
0.54 \text { ) and audit fees } \\
\text { Industry-specific concentration higher than total } \\
\text { concentration }\end{array}$ \\
\hline & $\begin{array}{l}\text { Beattie \& } \quad \& \\
\text { Fearnley } \\
(1994) \\
\end{array}$ & $\begin{array}{l}\mathrm{n}=2,079 \\
1987-1991\end{array}$ & $\begin{array}{l}\text { CR4, CR6, } \\
\text { CR8, CR20 }\end{array}$ & Number of audit assignments & $\begin{array}{l}\text { Increase of concentration (from CR4 }=0.43 \text { to } 0.59 \text { ) } \\
\text { (Mergers of audit firms and changes of auditors) }\end{array}$ \\
\hline & $\begin{array}{l}\text { Pearson \& } \\
\text { Trompeter } \\
(1994)\end{array}$ & $\begin{array}{l}\mathrm{n}=241 \\
1982-1986\end{array}$ & CR3 & $\begin{array}{l}\text { Number of audit assignments } \\
\text { Sales revenues }\end{array}$ & $\begin{array}{l}\text { Negative correlation between concentration and audit } \\
\text { fees }\end{array}$ \\
\hline & $\begin{array}{l}\text { Iyer \& Iyer } \\
(1996)\end{array}$ & $\begin{array}{l}n=270 \\
1987-1991\end{array}$ & $\begin{array}{l}\text { CR4, CR6, } \\
\text { CR8, CR20, } \\
\text { HHI }\end{array}$ & Audit fees & $\begin{array}{l}\text { Increase of concentration from CR4 }=0.45 \text { (1987) to } \\
0.57 \text { (1991) due to mergers } \\
\text { No evidence for increasing audit fees after merger }\end{array}$ \\
\hline & Peel (1997) & $\begin{array}{l}\mathrm{n}=1,865 \\
1995\end{array}$ & CR6 & $\begin{array}{l}\text { Number of audit assignments } \\
\text { Sales revenues } \\
\text { Audit fees }\end{array}$ & $\begin{array}{l}\text { Concentration rate } \mathrm{CR} 6=0.78 \\
\text { Market shares of Big Six vary depending on market } \\
\text { segment }\end{array}$ \\
\hline & Pong (1999) & $\begin{array}{l}\mathrm{n} \quad 1,211 \\
1,222, \quad 1,237 \\
1.320 \text { and } 1,401 \\
1991-1995\end{array}$ & $\begin{array}{l}\text { CR4, CR6, } \\
\text { CR8, HHI }\end{array}$ & $\begin{array}{l}\text { Number of audit assignments } \\
\text { Audit fees }\end{array}$ & $\begin{array}{l}\text { Only slight increase of concentration from CR } 4=0.57 \\
\text { to } 0.60 \text { (no mergers in this period) } \\
\text { Classified as oligopoly }\end{array}$ \\
\hline & $\begin{array}{l}\text { Beattie, } \\
\text { Goodacre \& } \\
\text { Fearnley } \\
(2003) \\
\end{array}$ & $\begin{array}{l}n=2,180 \\
2002-2003\end{array}$ & CR4, CR8 & $\begin{array}{l}\text { Number of audit assignments } \\
\text { Audit fees }\end{array}$ & Increasing concentration from $\mathrm{CR} 4=0.67$ to 0.73 \\
\hline & $\begin{array}{l}\text { Pong \& } \quad \& \\
\text { Burnett } \\
(2006)\end{array}$ & $\begin{array}{l}\mathrm{n}=1,280 \text { and } \\
1,094 \\
1997 \text { and } 2001\end{array}$ & CR4, CR6, HHI & $\begin{array}{l}\text { Number of audit assignments } \\
\text { Audit fees }\end{array}$ & $\begin{array}{l}\text { Increase of concentration from CR } 4=0.61 \text { to } 0.64 \\
\text { No positive correlation between increase of supplier } \\
\text { concentration and audit fees at PwC as market leader }\end{array}$ \\
\hline & $\begin{array}{l}\text { McMeeking, } \\
\text { Peasnell \& } \\
\text { Pope }(2007)\end{array}$ & $\begin{array}{l}\mathrm{n}=7,255 \\
1985-2002\end{array}$ & $\begin{array}{l}\text { CR4, CR5, } \\
\text { CR6, CR7 } \\
\text { CR8, HHI }\end{array}$ & $\begin{array}{l}\text { Number of audit assignments } \\
\text { Audit fees }\end{array}$ & $\begin{array}{l}\text { Positive correlation between concentration and audit } \\
\text { fees } \\
\text { Positive impact of mergers of audit firms on } \\
\text { concentration rates } \\
\text { Increasing concentration from CR } 4=0.65 \text { (1985) to } \\
0.83 \text { (2002) }\end{array}$ \\
\hline & $\begin{array}{l}\text { Abidin, } \\
\text { Beattie \& } \\
\text { Goodacre } \\
(2010)\end{array}$ & $\begin{array}{l}\mathrm{n} \quad 1,607 \\
1,498, \quad 1,479 \\
1,539, \quad 1,497 \\
\text { and } 1,386 \\
1998-2003\end{array}$ & $\begin{array}{l}\text { CR4, } \\
\text { CR20 } \\
\text { HHI, G }\end{array}$ & $\begin{array}{l}\text { Number of audit assignments } \\
\text { Audit fees }\end{array}$ & $\begin{array}{l}\text { Increase of concentration from CR } 4=0.67 \text { to } 0.68 \\
\text { (Engagements) and from } 0.88 \text { to } 0.96 \text { (Fees) } \\
\text { respectively } \\
\begin{array}{l}\text { Purchase of Arthur Andersen has reduced } \\
\text { disproportion of market shares held by big Audit firms }\end{array}\end{array}$ \\
\hline Netherlands & $\begin{array}{l}\text { Maijoor et al. } \\
(1995)\end{array}$ & $\begin{array}{l}\text { n.s. } \\
1880-1990\end{array}$ & CR4, HHI & $\begin{array}{l}\text { Auditors engaged per audit } \\
\text { firm }\end{array}$ & $\begin{array}{l}\text { Very little and equally remaining concentration rates } \\
\text { until the end of the } 1960 \mathrm{~s} \\
\text { Significant increase of concentration since } 1970 \text { due } \\
\text { to both regulation standards and mergers }\end{array}$ \\
\hline $\begin{array}{l}\text { Netherlands/ } \\
\text { Germany }\end{array}$ & $\begin{array}{l}\text { Buijink, } \\
\text { Maijoor \& } \\
\text { Meuwissen } \\
(1998)\end{array}$ & $\begin{array}{l}\text { n.s. } \\
1970-1994\end{array}$ & CR4, HHI & $\begin{array}{l}\text { Auditors engaged per Audit } \\
\text { firm } \\
\text { Number of subsidiaries }\end{array}$ & $\begin{array}{l}\text { Increasing concentration in the Netherlands from CR } 4 \\
=0.37 \text { up to } 0.52 \\
\text { Higher concentration than in Germany }(C 4=0.16)\end{array}$ \\
\hline Spain & $\begin{array}{l}\text { Romero et al. } \\
(1995)\end{array}$ & $\begin{array}{l}\mathrm{n}=250 \\
1991-1993\end{array}$ & $\begin{array}{l}\text { CR1-2, CR4, } \\
\text { CR6, HHI }\end{array}$ & $\begin{array}{l}\text { Number of Audit } \\
\text { assignments } \\
\text { Sales revenues }\end{array}$ & $\begin{array}{l}\text { Dominance of Big Six since the introduction of } \\
\text { statutory audit } \\
\text { Increasing concentration }\end{array}$ \\
\hline
\end{tabular}

\subsection{Non EU-member States}

\subsubsection{USA}

Among the non-EU-countries the empirical concentration research focuses mainly on the US capital market. The first concentration measurement worldwide was performed by Zeff and Fossum (1967). In doing so, the authors determined the distribution of audit engagements to Audit firms and their market shares for the business year 1964. Already in the first study a dominance of two or three audit firms in some market segments could be 
observed. Zeff and Fossum (1967) see indications of a sector specialization in the field of audit firms, without looking closer on its underlying reasons. Research work laid the foundation for numerous follow-up studies in both USA and other countries. Compared to Zeff and Fossum (1967) the follow-up study of Rhode, Whitsell and Kelsey (1974) in the business year 1972 can find an increasing dominance of the Big Eight.

Eichenseher and Danos (1981) and Danos and Eichenseher (1986) submitted the first multiperiodic studies with a great sample size. It can be demonstrated that the concentration on the audit market is greater for the audit of regulated industries than for non-regulated sectors. Moreover it can be shown that both large and growing companies improve the concentration of suppliers among the Big Eight audit firms. According to Danos and Eichenseher (1986), who base their research on the years 1950, 1960, 1970 and 1980, the concentration of suppliers in non-regulated industries decreases over time due to lower economies of scale. Tomczyk and Read (1989) take a closer look at the years 1983-1987 and find that the concentration of suppliers among the Big Four remains relatively stable at CR4 $=0.5$. Minyard and Tabor (1991) state that the mergers of the Big Eight to form the Big Six between 1983 and 1986 do not significantly influence the development of the concentration on the audit market. Also Tonge and Wootton (1991) find that no audit firm holds a market share of more than $20 \%$ in the business year 1988. Furthermore Wootton, Tonge and Wolk (1994) show an increasing equal distribution among the big audit firms for 1988. Though, the concentration in the field of auditing in 1990 is according to Penno and Walther (1998) significantly higher $(C R 4=0.53)$ than for companies in the law and advertising industry (CR4 $=0.45$ and 0.39). According to Francis, Stokes and Anderson (1999) Ernst \& Young is able to improve its market share towards a market leadership in 1988 and 1990 in those cities in which the audit firm has hold increasing market shares even before the consolidation process. Moreover they found that the national market or industry leader is not identical with the local market leader in different cities. Consequently, there are incidents for a divergence concerning the reputation of the audit firms in the respective cities. On the contrary, Wolk, Michelson and Wootton (2001) can prove increasing concentration rates due to mergers among both the Big Eight and Big Six in 1988, 1991, 1996 and 1999 [CR4 = 0.52 (1988) and 0.7 (1999)]. Also Caban-Garcia and Cammack (2009) state in analogy to other international studies, that there is an increase of concentration in the year after the merger of PriceWaterhouse and C\&L but also after the takeover of Arthur Andersen by Ernst \& Young. Though, the concentration starts to decline already two years after the mergers.

In a more recent study Kallapur, Sankaraguruswamy and Zhang (2010) discover a positive correlation between the concentration rate at a city level and the quality of accounting for 2000-2006. Thus, an increasing concentration of suppliers does not necessarily result in negative effects on the quality of the audit, contrary to the opinion of the EU commission. Increasing concentrations are likewise measured by Dunn, Kohlbeck and Mayhew (2011) for 2001-2007 whereas in analogy to Wootton, Tonge and Wolk (1994) an increasing equivalence of the market shares among the Big Four is visible.

\subsubsection{Switzerland}

In her study of market concentration in Switzerland, Heer (2001) can assess a high provider concentration as well as an increase over time for 1994, 1997 and 1998. Stefani (2006) proves a dominance of PwC (52.1\%) towards Ernst \& Young (24.5\%) and KPMG (21.1\%) for 2002. The concentration ratios tend to be higher than in comparable studies for the German audit market. The merger of PriceWaterhouse and C\&L for PwC as well as the fusion between Arthur Andersen and Ernst \& Young has not led to a significant increase of the absolute concentration (in terms of the balance sheet total). Stefani (2006) speculates that the external growth of the largest audit firms was balanced by the negative internal growth of the market leader PwC. Breitkreuz and Müßig (2010) state, that the Swiss audit market is divided as well on the Big Three. Deloitte has a minor market share, while Ernst \& Young, KPMG and $\mathrm{PwC}$ have over time a relative consistent market share of approximately $95 \%$. The concentration ratios are over time relative stable.

\subsubsection{Australia}

Gilling and Stanton (1978) show an increased concentration of suppliers for both 1971 and 1976, thus an immaterial increase over time (from CR4 $=0.50$ to 0.51 ) as well as the dominance of a small number of audit firms. Thavapalan, Moroney and Simnett (2003) state that three out of 24 industries are entirely served by the Big Four, on an industry-specific analysis for the business years 1997 and 1999. An increasing concentration is visible in almost all industries which is based on the merger of PriceWaterhouse and C\&L.

\subsubsection{Bangladesh}

Karim (2010) could not discover high market shares of the Big Four compared with those in industrial countries for 1990-2003, which shows that there is little concentration of suppliers in developing countries. 


\subsubsection{China}

Lee (1994) observes a declining concentration in the Chinese audit market over time for the years 1980, 1984 and 1989, although the concentration rates achieve a higher level than in comparable US studies. DeFond, Wong and $\mathrm{Li} \mathrm{(2000)}$ can also prove decreasing market shares of the Big Ten in China due to stricter auditing standards concerning independence.

\subsubsection{Canada}

According to Shaw and Archibald (1970) the Big Three audit firms test 1/3 of the sample in 1968. In 10 of 25 industries PwC holds the greatest market share.

\subsubsection{New Zealand}

Johnson, Walker and Westergaard (1995) state very high concentration measures of CR4 $=0.89$ and CR5 $=0.96$, which are significantly higher than those of the USA or Great Britain in 1989. Furthermore a price premium of the Big Five can be noticed.

\subsubsection{Conclusion}

The increasing concentration of suppliers in the audit market of non-EU-countries, as shown in Table 2, is consistently proven, although the shares of the respective firms differ. Thus, the concentration of suppliers in the audit market is a permanent, worldwide phenomenon which occurs not only in outsider but also in insider systems of corporate governance. The increasing concentration of suppliers is caused by economies of scale, growing needs of the clients regarding business establishments across national boundaries of the audit firms and prior mergers of audit companies. Both, the merger of C\&L and PriceWaterhouse (Big Five) in 1998 as well as the takeover of Arthur Andersen by Ernst \& Young (Big Four) in 2002 were discussed as main determinants in the previously regarded studies. In addition the few existing cross-border investigation projects should be noted.

Table 2. Empirical research on audit markt concentration in non EU member states

\begin{tabular}{|c|c|c|c|c|c|}
\hline Country & $\begin{array}{l}\text { Author(s) } \\
\text { and Year of } \\
\text { publication }\end{array}$ & $\begin{array}{l}\text { Sample } \\
\text { Observation } \\
\text { period }\end{array}$ & $\begin{array}{l}\text { Method of } \\
\text { concentration } \\
\text { measurement }\end{array}$ & $\begin{array}{l}\text { Variables for measurement } \\
\text { of market share }\end{array}$ & Main results \\
\hline \multirow[t]{3}{*}{ Switzerland } & Heer (2001) & $\begin{array}{l}\mathrm{n}=618 \\
1994,1997 \text { and } \\
1998\end{array}$ & $\begin{array}{l}\text { CR3-CR6, HHI, } \\
\text { G, NE }\end{array}$ & $\begin{array}{l}\text { Number of Audit assignments } \\
\text { Sales revenues (absolute and } \\
\text { square root) }\end{array}$ & $\begin{array}{l}\text { High concentration of suppliers and increase over } \\
\text { time }\end{array}$ \\
\hline & $\begin{array}{l}\text { Stefani } \\
(2006)\end{array}$ & $\begin{array}{l}n=164,183 \\
174 \\
1996,2001 \text { and } \\
2002\end{array}$ & $\begin{array}{l}\text { CR1-CR4, CR6, } \\
\text { G, HHI, NE }\end{array}$ & $\begin{array}{l}\text { Number of audit assignments } \\
\text { Total assets (absolute and } \\
\text { square root) } \\
\text { Sales revenues (absolute and } \\
\text { square root) }\end{array}$ & $\begin{array}{l}\text { Market leadership of PwC } \\
\text { Big three hold market share of } 85.63 \% \\
\text { (Engagements) and } 98.42 \% \text { (Total assets) }\end{array}$ \\
\hline & $\begin{array}{l}\text { Breitkreuz \& } \\
\text { Müßig (2010) }\end{array}$ & $\begin{array}{l}n=671 \\
2005-2008\end{array}$ & - & $\begin{array}{l}\text { Number of audit assignments } \\
\text { Audit fees in total }\end{array}$ & $\begin{array}{l}\text { Concentration values remain relatively stable over } \\
\text { time } \\
\text { Market share of Big Three from } 96 \% \text { (Fees) and } \\
85 \% \text { (Engagements) respectively in } 2008 \\
\text { Insignificant market share of Deloitte }\end{array}$ \\
\hline \multirow[t]{2}{*}{ Australia } & $\begin{array}{l}\text { Gilling \& } \\
\text { Stanton } \\
(1978)\end{array}$ & $\begin{array}{l}\mathrm{n}=415 \\
1971 / \\
1976\end{array}$ & $\begin{array}{l}\text { CR4, CR8, } \\
\text { HHI, G, NE }\end{array}$ & $\begin{array}{l}\text { Number of audit assignments } \\
\text { Total assets } \\
\text { Net profit } \\
\text { Equity base }\end{array}$ & $\begin{array}{l}\text { Only negligible increase of concentration from } \\
\text { CR4 }=0.5 \text { (1971) to } 0.51(1976) \\
\text { Lower concentration rates compared to other } \\
\text { industrial countries }\end{array}$ \\
\hline & $\begin{array}{l}\text { Thavapalan, } \\
\text { Moroney \& } \\
\text { Simnett } \\
(2002)\end{array}$ & $\begin{array}{l}\mathrm{n}=1,085 \text { and } \\
1,083 \\
1997 \text { and } 1999\end{array}$ & CR4, HHI & $\begin{array}{l}\text { Number of audit assignments } \\
\text { Audit fees }\end{array}$ & $\begin{array}{l}\text { Three of } 24 \text { industries are entirely audited by Big } \\
\text { Four } \\
\text { Increasing concentrations in almost all industries } \\
\text { from } 1997 \text { to } 1999 \text { (merger of PriceWaterhouse and } \\
\text { C\&L) }\end{array}$ \\
\hline Bangladesh & Karim (2010) & $\begin{array}{l}\mathrm{n}=208 \\
1990-2003\end{array}$ & $\begin{array}{l}\text { CR4, } \\
\text { CR16 }\end{array}$ & $\begin{array}{l}\text { Number of audit assignments } \\
\text { Audit fees }\end{array}$ & $\begin{array}{l}\text { No high market shares of the Big Four in } \\
\text { comparison to industrial countries }\end{array}$ \\
\hline China & Lee (1994) & $\begin{array}{l}\mathrm{n}=232,242 \\
\text { and } 279 \\
1980,1984 \text { and } \\
1989\end{array}$ & $\begin{array}{l}\text { CR4, } \\
\text { CR9, } \\
\text { HHI }\end{array}$ & $\begin{array}{l}\text { Number of audit assignments } \\
\text { Sales revenues (absolute and } \\
\text { square root) } \\
\text { Total assets (absolute and } \\
\text { square root) } \\
\text { Equity base (absolute and } \\
\text { square root) } \\
\text { Net profit (absolute and square }\end{array}$ & $\begin{array}{l}\text { Decline of concentration over time, though higher } \\
\text { level than in the USA } \\
\text { Partially industry-specific shares higher than those } \\
\text { across industries }\end{array}$ \\
\hline
\end{tabular}




\begin{tabular}{|c|c|c|c|c|c|}
\hline Country & $\begin{array}{l}\text { Author(s) } \\
\text { and Year of } \\
\text { publication }\end{array}$ & $\begin{array}{l}\text { Sample } \\
\text { Observation } \\
\text { period }\end{array}$ & $\begin{array}{l}\text { Method of } \\
\text { concentration } \\
\text { measurement }\end{array}$ & $\begin{array}{l}\text { Variables for measurement } \\
\text { of market share }\end{array}$ & Main results \\
\hline & & & & root) & \\
\hline & & & & Audit Fees & \\
\hline & $\begin{array}{l}\text { DeFond, } \\
\text { Wong, \& } \\
\text { Li (2000) }\end{array}$ & $\begin{array}{l}n=1,286 \\
1993-1996\end{array}$ & - & $\begin{array}{l}\text { Number of audit assignments } \\
\text { Sales revenues }\end{array}$ & $\begin{array}{l}\text { Decreasing market share of Big Ten due to } \\
\text { restrictive auditing standards concerning } \\
\text { independence }\end{array}$ \\
\hline Canada & $\begin{array}{l}\text { Shaw \& } \\
\text { Archibald } \\
(1970)\end{array}$ & $\begin{array}{l}\mathrm{n}=927 \\
1968\end{array}$ & - & $\begin{array}{l}\text { Number of audit assignments } \\
\text { Total assets }\end{array}$ & $\begin{array}{l}\text { Big Three audit } 381 \text { businesses (Number of audit } \\
\text { assignments) } \\
\text { PwC has the highest market share in } 10 \text { out of } 25 \\
\text { industries (Total assets) }\end{array}$ \\
\hline $\begin{array}{l}\text { New } \\
\text { Zealand }\end{array}$ & $\begin{array}{l}\text { Johnson, } \\
\text { Walker \& } \\
\text { Westergaard } \\
(1995)\end{array}$ & $\begin{array}{l}\mathrm{n}=259 \\
1989\end{array}$ & CR4, CR5 & Audit fees & $\begin{array}{l}\text { Very high concentration }(\mathrm{CR} 4=0.96) \\
\text { Significantly higher concentration than in the USA } \\
\text { and Great Britain } \\
\text { Provides evidence for price premium among Big } \\
\text { Five }\end{array}$ \\
\hline \multirow[t]{12}{*}{ USA } & $\begin{array}{l}\text { Zeff \& } \\
\text { Fossum } \\
(1967)\end{array}$ & $\begin{array}{l}\mathrm{n}=526 \\
1964\end{array}$ & - & $\begin{array}{l}\text { Number of Audit assignments } \\
\text { Total assets } \\
\text { Sales revenues } \\
\text { Net income }\end{array}$ & $\begin{array}{l}\text { Dominance of Bigh Eight } \\
\text { Diverging industry-specific market shares }\end{array}$ \\
\hline & $\begin{array}{l}\text { Rhode, } \\
\text { Whitsell \& } \\
\text { Kelsey } \\
(1974) \\
\end{array}$ & $\begin{array}{l}\mathrm{n}=619 \\
1972\end{array}$ & - & $\begin{array}{l}\text { Number of audit assignments } \\
\text { Total assets } \\
\text { Sales Revenues } \\
\text { Annual Surplus } \\
\end{array}$ & $\begin{array}{l}\text { Increasing dominance of Big Eight compared to } \\
\text { Zeff/Fossum }\end{array}$ \\
\hline & $\begin{array}{l}\text { Eichenseher } \\
\& \quad \text { Danos } \\
(1981)\end{array}$ & $\begin{array}{l}\mathrm{n}=4,900 \\
1977-1978\end{array}$ & CR4, HHI & $\begin{array}{l}\text { Number of audit assignments } \\
\text { Sales revenues (absolute and } \\
\text { square root) }\end{array}$ & $\begin{array}{l}\text { Lower supplier concentration compared to previous } \\
\text { studies } \\
\text { Higher concentration in regulated industries due to } \\
\text { economies of scale }\end{array}$ \\
\hline & $\begin{array}{l}\text { Danos \& } \\
\text { Eichenseher } \\
(1986)\end{array}$ & $\begin{array}{l}\mathrm{n} \quad 2,856 \\
3,047, \quad 2,914 \\
\text { and } 8,098 \\
1950, \quad 1960, \\
1970 \text { and } 1980\end{array}$ & CR8 & Number of audit assignments & $\begin{array}{l}\text { Supplier concentration in non-regulated industries } \\
\text { decreases over time due to lower economies of } \\
\text { scale }\end{array}$ \\
\hline & $\begin{array}{l}\text { Tomczyk \& } \\
\text { Read (1989) }\end{array}$ & $\begin{array}{l}\text { n.s. } \\
1983-1987\end{array}$ & $\begin{array}{l}\text { CR4, CR8, CR } \\
16, \mathrm{HHI}\end{array}$ & Audit fees & $\begin{array}{l}\text { Concentration remains stable over time (CR4 } \\
\text { approx. 0.5) } \\
\text { Slightly lower concentration measures compared to } \\
\text { previous studies }\end{array}$ \\
\hline & $\begin{array}{l}\text { Minyard \& } \\
\text { Tabor (1991) }\end{array}$ & $\begin{array}{l}\mathrm{n}=1,618 \\
1983-1988\end{array}$ & HHI & $\begin{array}{l}\text { Sales revenues (absolute and } \\
\text { square root) }\end{array}$ & $\begin{array}{l}\text { Mergers of Big Eight to form Big Six do not have a } \\
\text { significant influence on the concentration }\end{array}$ \\
\hline & $\begin{array}{l}\text { Tonge \& } \\
\text { Wootton } \\
(1991)\end{array}$ & $\begin{array}{l}\mathrm{n}=5,962 \\
1988\end{array}$ & CR4, CR8 & $\begin{array}{l}\text { Number of audit assignments } \\
\text { (absolute and square root) } \\
\text { Market capitalisation (absolute } \\
\text { and square root) }\end{array}$ & $\begin{array}{l}\text { Despite high concentration values }(C R 4=0.69) \text { no } \\
\text { Audit firm holds a market share higher than } 20 \%\end{array}$ \\
\hline & $\begin{array}{l}\text { Wootton, } \\
\text { Tonge \& } \\
\text { Wolk (1994) }\end{array}$ & $\begin{array}{l}\mathrm{n}=5,962 \text { and } \\
5,777 \\
1988 \text { and } 1991\end{array}$ & $\begin{array}{l}\text { CR4, CR6, } \\
\text { CR8, HHI }\end{array}$ & $\begin{array}{l}\text { Number of audit assignments } \\
\text { Audit fees } \\
\text { Sales revenues (square root) }\end{array}$ & $\begin{array}{l}\text { Increasing concentration over time according to CR } \\
\text { Mainly increasing equal distribution among the big } \\
\text { Audit companies according to } \mathrm{HHL}\end{array}$ \\
\hline & $\begin{array}{l}\text { Penno \& } \\
\text { Walther } \\
(1996)\end{array}$ & $\begin{array}{l}\mathrm{n}=1,110 \\
1990\end{array}$ & $\mathrm{CR} 4, \mathrm{HHI}$ & $\begin{array}{l}\text { Auditors employed by audit } \\
\text { firm }\end{array}$ & $\begin{array}{l}\text { Concentration in the field of audit significantly } \\
\text { higher }(\mathrm{CR} 4=0.53) \text { than for companies in the law- } \\
\text { and advertising-industries }(\mathrm{CR} 4=0.45 \text { und } 0.39 \text { ) }\end{array}$ \\
\hline & $\begin{array}{l}\text { Francis, } \\
\text { Stokes \& } \\
\text { Anderson } \\
(1999)\end{array}$ & $\begin{array}{l}\text { n.s. } \\
1988 \text { and } 1990\end{array}$ & CR8 & $\begin{array}{l}\text { Number of audit assignments } \\
\text { Sales revenues } \\
\text { Market value }\end{array}$ & $\begin{array}{l}\text { Generally no identity between national market- or } \\
\text { industry-leader and local leader in different urban } \\
\text { areas } \\
\text { Signs for diverging reputation of the audit firms } \\
\text { according to urban area }\end{array}$ \\
\hline & $\begin{array}{l}\text { Wolk, } \\
\text { Michelson \& } \\
\text { Wootton } \\
(2001)\end{array}$ & $\begin{array}{l}\mathrm{n} \quad 5,962 \\
5,777, \quad 7,639 \\
\text { and } 7,216 \\
1988, \quad 1991, \\
1996 \text { and } 1999\end{array}$ & $\begin{array}{l}\text { CR4, CR6, } \\
\text { CR8, HHI }\end{array}$ & Number of audit assignments & $\begin{array}{l}\text { Increasing concentration rates over time due to } \\
\text { mergers among Big Eight and Big Six } \\
\text { Increase from CR } 4=0.52(1988) \text { to } 0.70(1999)\end{array}$ \\
\hline & $\begin{array}{l}\text { Caban- } \\
\text { Garcia \& } \\
\text { Cammack } \\
(2009)\end{array}$ & $\begin{array}{l}\mathrm{n}=14,758 \\
15,340, \quad 13,893 \\
\text { and } 11,999 \\
1997, \quad 1999, \\
2001 \text { and } 2003\end{array}$ & CR4, HHI & $\begin{array}{l}\text { Number of audit assignments } \\
\text { Sales revenues }\end{array}$ & $\begin{array}{l}\text { Increase of concentration in the year after the } \\
\text { merger of PriceWaterhouse and C\&L and the } \\
\text { takeover of Arthur Andersen by Ernst \& Young } \\
\text { Decreasing concentration rates two years after the } \\
\text { merger }\end{array}$ \\
\hline
\end{tabular}




\begin{tabular}{|c|c|c|c|c|c|}
\hline Country & $\begin{array}{l}\text { Author(s) } \\
\text { and Year of } \\
\text { publication }\end{array}$ & $\begin{array}{l}\text { Sample } \\
\text { Observation } \\
\text { period }\end{array}$ & $\begin{array}{l}\text { Method of } \\
\text { concentration } \\
\text { measurement }\end{array}$ & $\begin{array}{l}\text { Variables for measurement } \\
\text { of market share }\end{array}$ & Main results \\
\hline & $\begin{array}{l}\text { Kallapur, } \\
\text { Sankarag-uru }\end{array}$ & \multirow[t]{2}{*}{$\begin{array}{l}\mathrm{n}=27,756 \\
2000-2006\end{array}$} & \multirow[t]{2}{*}{ HHI } & \multirow[t]{2}{*}{$\begin{array}{l}\text { Number of audit assignments } \\
\text { Audit fees }\end{array}$} & $\begin{array}{l}\text { Positive correlation between concentration rate at } \\
\text { city level and accounting quality }\end{array}$ \\
\hline & $\begin{array}{l}\text { swamy \& } \\
\text { Zang (2010) }\end{array}$ & & & & $\begin{array}{l}\text { Increasing concentration of Big Four over time } \\
\text { Increasing equivalence of market shares among } \\
\text { Big Four }\end{array}$ \\
\hline & $\begin{array}{l}\text { Dunn, } \\
\text { Kohlbeck \& } \\
\text { Mayhew } \\
(2011)\end{array}$ & $\begin{array}{l}\mathrm{n}=47 \\
2001-2007\end{array}$ & CR4, G, HHI & $\begin{array}{l}\text { Number of audit assignments } \\
\text { Audit fees }\end{array}$ & $\begin{array}{l}\text { Increasing concentration of Big Four over time } \\
\text { Increasing equivalence of market shares among } \\
\text { Big Four }\end{array}$ \\
\hline
\end{tabular}

\section{Conclusion}

In her regulation drafts of 2011, the EC indicated the risks of an increasing concentration on the European audit market. Small and medium sized audit firms are increasingly driven out from the audit of capital market oriented companies which leads to significant disadvantages of competition along with rising oligopolistic rents for the big audit firms. This paper predominantly focused on the current results of the empirical research on concentration measurement in EU-member states in comparison to non-EU-member-states. Since the initial measurement in Germany, an increasing concentration development for the audits of listed companies on the European audit market can be proved (Velte, 2011). The empirical concentration measurement gained validity by the disclosure requirements for the (non) audit fees in the notes of the mandates as well as in the transparency reports of audit firms. As a result, a deduction of the market shares must not singly undertaken by surrogate figures (e.g. balance sheet total, sales revenue). The supplier concentration on the European audit market, which is reflected as an oligopolization of few big audit firms, is not a national phenomenon, but can be empirically demonstrated in many EU member states. The critical points of the studies are that not in any case an appropriate sample size and length of the evaluation period was selected. Exceptions are the studies of Schaen and Maijoor (10.692), Beattie and Fearnley (2.079), Peel (171.799) relating to the sample size and relating to the evaluation period the studies of Briston and Kedslie (1928-1984) and Maijoor et al. (1880-1990).

However, the valuation by the EC that a high audit market concentration must be connected with a restraint of competition, can often not proved empirically. Furthermore it is vague, how the EC reforms for a concentration decrease, e.g. the introduction of a mandatory audit firm rotation, are connected to an increased audit quality. Instead, significant increasing transaction costs could be related hereby which could without suppression of price dumping strategies (low balling) endanger the audit quality. Against this background, arise first of all a need to implement a minimum audit fee which should at least cover the individual costs of the audit firms.

Thus, from an economic point of view it seems questionable in how far audit firm concentration is an issue for regulation by the EC. This is also be stressed by the fact that the requirements for listed firms with respect to accounting and auditing may only hardly be fulfilled by small and medium-sized audit firms. This is caused by missing international networks and limited capacities (time, manpower and competence). When a medium-sized audit firm (with limited capacities) processes the audit of a multi-national listed firm this causes higher risk to strongly depend on the firm since losing this mandate would cause high financial risk for the audit firm itself (as a consequence the independence of the audit firm is highly questionable). Insofar, the current concentration on the audit markets is an expression of natural market mechanisms which is supported by the mandate firms.

\section{References}

Abidin, S., Beattie, V., \& Goodacre, A. (2010). Audit market structure, fees and choice in a period of structural change. British Accounting Review, 2(3), 187-206. http://dx.doi.org/10.1016/j.bar.2010.04.002

Bauer, M. (2004). Die Unabhaengigkeit des Abschlusspruefers im Zusammenhang mit dem gleichzeitigen Angebot von Beratungsleistungen beim Pruefungsmandanten. Wuerzburg: Julius-Maximilians-University.

Beattie, V., \& Fearnley, S. (1994). The Changing Structure of the Market for Audit Services in the UK. British Accounting Review, 26(4), 301-322. http://dx.doi.org/10.1006/bare.1994.1021

Beattie, V., Goodacre, A., \& Fearnley, S. (2003). And then were four: A study of UK audit market concentration. Journal of Financial Regulation and Compliance, 11(3), 250-265. http://dx.doi.org/10.2139/ssrn.389544

Bigus, J., \& Zimmermann, R. C. (2008). Non audit fees, market leaders and concentration in the German audit $\begin{array}{lllll}\text { market. International Journal of } & \text { Auditing, } & 12(3),\end{array}$ 
http://dx.doi.org/10.1111/j.1099-1123.2008.00378.x

Breitkreuz, R., \& Mueßig, A. (2010). Kritische Analyse der Anbieterkonzentration auf dem Schweizer Markt für Revisions- und Beratungsleistungen. Kapitalmarktorientierte und internationale Rechnungslegung, 11(10), 510-514.

Briston, R., \& Kedslie, M. (1985). Must Smaller Firms Continue to Lose Out? Accountancy, 12(3), 163-164.

Buijink, W. F. J., Maijoor, S. J., \& Meuwissen, R. H. G. (1998). Competition in Auditing. Contemporary Accounting Research, 15(3), 385-404. http://dx.doi.org/10.1111/j.1911-3846.1998.tb00565.x

Caban-Garcia, M. T., \& Cammack, S. E. (2009). Audit Firm Concentration and Competition. Journal of Theoretical Accounting Research, 25(5), 1-24.

Cammack, S. E., \& Caban-Garcia, M. T. (2005). Audit Firm Concentration and Competition Effects of Consolidation Since 1997. http://info.cba.ksu.edu/skovar/centralstates/2005/Cammack.pdf.

Christiansen, M., \& Loft, A. (1992). Big players and small players: a study of increasing concentration in the Danish Market for Auditing services. The European Accounting Review, 1(2), 277-301. http://dx.doi.org/10.1080/09638189200000024

Danos, P., \& Eichenseher, J. W. (1986). Long-Term Trends toward Seller Concentration in the U.S. Audit Market. Accounting Review, 61(3), 633-650.

DeAngelo, L. E. (1981). Auditor Size and Audit quality. Journal of Accounting and Economics, 3(3), 183-199. http://dx.doi.org/10.1016/0165-4101(81)90002-1

DeFond, M. L., Wong, T. J., \& Li, S. (2000). The impact of improved auditor independence on audit market concentration in China. Journal of Accounting and Economics, 22(4), 269-305. http://dx.doi.org/10.2308/aud.2000.19.1.49

Dunn, K., Kohlbeck, M., \& Mayhew, B. W. (2011). The Impact of the Big 4 Consolidation on Audit Market Share Equality. Auditing, 30(1), 49-73. http://dx.doi.org/10.2308/aud.2011.30.1.49

EC. (2010). Audit Policy: Lessons from the crisis. http://ec.europa.eu/internal_market/consultations/docs/2010/audit/green_paper_audit_en.pdf.

EC. (2011a). Vorschlag fuer eine Richtlinie des Europaeischen Parlaments und des Rates zur Aenderung der Richtlinie 2006/43/EG ueber Abschlusspruefungen von Jahresabschluessen und konsolidierten Abschluessen (KOM(2011) 778/2.

EC. (2011b). Vorschlag fuer eine Verordnung des Europaeischen Parlaments und des Rates ueber spezifische Anforderungen an die Abschlusspruefung bei Unternehmen von oeffentlichem Interesse $(\operatorname{KOM}(2011)$ $779 / 4$.

Eichenseher, J. W., \& Danos, P. (1981). The analysis of industry-specific auditor concentration. Accounting Review, 56(5), 479-492.

Francis, J. R., Michas, P. N., \& Seavey, S. E. (2011). Does Audit Market Concentration Harm the Quality of Audited Earnings? Evidence from Audit Markets in 42 Countries. http://dx.doi.org/10.2139/ssrn.1948687

Francis, J. R., Stokes, D. J., \& Anderson, D. (1999). City Markets as a Unit of Analysis in Audit Research and the Re-Examination of Big 6 Market Shares. Abacus, 35(2), 185-206. http://dx.doi.org/10.1111/1467-6281.00040

Freidank, C. Chr., \& Velte, P. (2012). Anbieterkonzentration am internationalen Pruefungsmarkt und Einfluss auf die Pruefungsqualitaet. Zeitschrift fuer Corporate Governance, 7(1), 26-34.

Gilling, D. M., \& Stanton, P. J. (1978). Changes in the Structure of the Auditing Profession in Australia. Abacus, 14(1), 66-80. http://dx.doi.org/10.1111/j.1467-6281.1978.tb00058.x

Grothe, J. (2005). Branchenspezialisierungen von Wirtschaftspruefungsgesellschaften im Rahmen der Jahresabschlusspruefung. Duesseldorf: IDW.

Hachmeister, D. (2001). Wirtschaftspruefungsgesellschaften im Pruefungsmarkt. Stuttgart: Schaeffer-Poeschel.

Heer, A. (2001). Konzentrationstendenzen in der Wirtschaftsprueferbranche. Aachen: Shaker.

House of Lords. (2011). Auditors: Market concentration and their role. www.publications.parliament.uk/pa/ld201011/ldselect/ldeconaf/119/119.pdf.

Huellweck, J. K., \& Ostrowski, M. (2000). Die Abschlusspruefer boersennotierter Aktiengesellschaften. 
Wirtschaftsprueferkammer-Mitteilungen, 12(1), 2-9.

Iyer, V. M., \& Iyer, G. S. (1996). Effect of Big 8 Mergers on Audit Fees: evidence from the United Kingdom. Auditing, 15(2), 123-132.

Johnson, E. N., Walker, K. B., \& Westergaard, E. (1995). Supplier Concentration and Pricing of Audit Services in New Zealand. Auditing, 14(1), 74-89.

Kallapur, S., Sankaraguruswamy, S., \& Zang, Y. (2010). Audit Market Concentration and Audit Quality. Working Paper, Gachibowli. http://dx.doi.org/10.1596/1813-9450-5493

Karim, A. K. M. W. (2010). Audit Pricing, Audit Concentration and Big 4-Premium in Bangladesh. Working Paper, Moraga. http://dx.doi.org/10.2139/ssrn.1613454

Koehler, A. G., Marten, K. U., Ratzinger, N. V. S., \& Wagner, M. (2010). Pruefungshonorare in Deutschland. Zeitschrift fuer Betriebswirtschaft, 80(1), 5-29.

Lee, D. S. (1994). Further Evidence on auditor concentration. International Journal of Accounting, 29(3), 234-250.

Lenz, H., \& Bauer, M. (2004). Pruefungs- und Beratungshonorare von Abschlusspruefern deutscher boersennotierter Aktiengesellschaften. Die Wirtschaftspruefung, 57(12), 985-998.

Lenz, H., Moeller, M., \& Hoehn, B. (2006). Offenlegung der Honorare fuer Abschlussprueferleistungen im Geschaeftsjahr 2005 bei DAX-Unternehmen. Betriebs-Berater, 61(33), 1787-1793.

Loft, A., \& Sjoefors, A. (1993). Audit concentration in Sweden and Denmark. In Artsberg, K., Loft, A. \& Yard, S. (Eds.), Accounting Research in Lund (pp. 155-175). Lund: University Press.

Maijoor, S., Buijink, W., Witteloostuijn, A., \& Zinken, M. (1995). Long-Term Concentration in the Dutch Audit Market. Abacus, 31(2), 152-177. http://dx.doi.org/10.1111/j.1467-6281.1995.tb00360.x

McMeeking, K. P., Peasnell, K. V., \& Pope, P. F. (2007). The effect of large audit firm mergers on audit pricing in the UK. Accounting and Business Research, 37(4), 301-319. http://dx.doi.org/10.1080/00014788.2007.9663314

Minyard, D. H., \& Tabor, R. H. (1991). The Effect of Big Eight Mergers on Auditor Concentration. Accounting Horizons, 5(1), 79-90.

Moeller, M., \& Hoellbacher, A. (2009). Die deutsche Boersen- und Indexlandschaft und der Markt fuer Abschlussprüfungen. Die Betriebswirtschaft, 69(6), 647-678.

Moizer, P., \& Turley, S. (1989). Changes in the UK market for audit services: 1972-1982. Journal of Business Finance \& Accounting, 16(1), 41-53. http://dx.doi.org/10.1111/j.1468-5957.1989.tb00003.x

Oxera. (2007). Ownership rules of audit firms and their consequences for audit market concentration. http://ec.europa.eu/internal_market/auditing/docs/market/oxera_report_en.pdf.

Palmrose, Z. V. (1986). Audit fees and auditor size. Journal of Accounting Research, 24(1), 97-110. http://dx.doi.org/10.2307/2490806

Pearson, T., \& Trompeter, G. (1994). Competition in the market for audit services. Contemporary Accounting Research, 11(1), 115-135. http://dx.doi.org/10.1111/j.1911-3846.1994.tb00439.x

Peel, M. J. (1997). UK Auditor Concentration. Accounting and Business Research, 27(4), 311-322. http://dx.doi.org/10.1080/00014788.1997.9729557

Penno, M., \& Walther, B. R. (1996). The Concentration of Local Markets. Accounting Horizons, 10(1), 88-99.

Pong, C. K. M (1999). Auditor Concentration. Journal of Business Finance \& Accounting, 26(3-4), 451-475. http://dx.doi.org/10.1111/1468-5957.00263

Pong, C. M., \& Whittington, G. (1994). The determinants of audit fees. Journal of Business Finance and Accounting, 21(8), 1071-1095. http://dx.doi.org/10.1111/j.1468-5957.1994.tb00365.x

Pong, C., \& Burnett, S. (2006). The implications of merger for market share, audit pricing and non-audit fee-income. Managerial Auditing Journal, 21(1), 7-22. http://dx.doi.org/10.1108/02686900610634720

Porter, M. E. (2008). Competitive Strategy (11th ed.). New York: Campus.

Quick, R., \& Sattler, M. (2011). Das Erfordernis der Umsatzunabhaengigkeit und die Konzentration auf dem deutschen Markt fuer Abschlussprueferleistungen. Zeitschrift fuer Betriebswirtschaft, 81(1), 61-98. 
http://dx.doi.org/10.1007/s11573-010-0425-8

Rama, D. V., \& Read, W. J. (2006). Resignations by the Big 4 and the market for audit services. Accounting Horizons, 20(2), 97-109. http://dx.doi.org/10.2308/acch.2006.20.2.97

Rhode, J. G., Whitsell, G. M., \& Kelsey, R. L. (1974). An analysis of client-industry concentration for large public accounting firms. Accounting Review, 49(8), 772-787.

Romero, C., Benau, M. A. G., Barbadillo, E. R., \& Martinez, A. V. (1995). The Audit Market in Spain. Valencia: Working Paper.

Sattler, M. (2011). Vereinbarkeit von Abschlusspruefung und Beratung. Wiesbaden: Gabler. http://dx.doi.org/10.1007/978-3-8349-6393-2

Schaen, M., \& Maijoor, S. (1997). The Structure of the Belgian Audit Market. International Journal of Auditing, 1(2), 151-162. http://dx.doi.org/10.1111/1099-1123.00019

Shaw, D. C., \& Archibald, T. R. (1970). A client-based analysis of Canada's Public Accounting Profession. Canadian Chartered Accountant, 162-167.

Stefani, U. (2006). Anbieterkonzentration bei Pruefungsmandaten boersennotierter Schweizer Aktiengesellschaften. Die Betriebswirtschaft, 66(2), 121-145.

Thavaplan, S., Moroney, R., \& Simnett, R. (2002). The effect of the Pricewaterhouse Coopers merger on auditor concentration in Australia. Accounting and Finance, 42(2), 153-167. http://dx.doi.org/10.1111/1467-629X.00014

Tomczyk, S., \& Read, W. J. (1989). Direct Measurement of Supplier Concentration in the Market for Audit Services. Auditing, 9(2), 98-106.

Tonge, S. D., \& Wootton, C. W. (1991). Auditor Concentration and Competition Among the Large Public Accounting Firms. Journal of Accounting and Public Policy, 10(3), 157-172. http://dx.doi.org/10.1016/0278-4254(91)90010-H

United States General Accounting Office. (2003). Public Accounting Firms: Mandated Study on Consolidation and Competition. In: www.gao.gov/new.items/d03864.pdf.

United States General Accounting Office. (2008). Audits of Public Companies - Continued Concentration in Audit Market for large Public Companies does not call for Immediate Action. www.gao.gov/new.items/d08163.pdf.

Velte, P. (2011). Empirische Evidenz der Anbieterkonzentration am deutschen Pruefungsmarkt. Kapitalmarktorientierte und internationale Rechnungslegung, 11(12), 594-599. http://dx.doi.org/10.1007/s11301-011-0077-y

Walker, K. B., \& Johnson, E. N. (1996). A Review and Synthesis of Research on Supplier Concentration, Quality and Fee Structure in Non-U.S. Markets for Audit Services. International Journal of Accounting, 31(1), 1-18. http://dx.doi.org/10.1016/S0020-7063(96)90010-2

Weets, V., \& Jegers, M. (1997). Are the Big Six big in Belgium? European Accounting Review, 6(4), 773-789. http://dx.doi.org/10.1080/09638189700000017

Willekens, M., \& Achmadi, C. (2003). Pricing and supplier concentration in the private client segment of the audit market. International Journal of Accounting, 38(4), 431-455. http://dx.doi.org/10.1016/j.intacc.2003.09.009

Wolk, C., Michelson, S., \& Wootton, C. (2001). Auditor concentration and market shares in the US. British Accounting Review, 33(2), 157-174. http://dx.doi.org/10.1006/bare.2001.0159

Wootton, C. W., Tonge, S. D., \& Wolk, C. M. (1994). Pre and Post Big 8 Mergers. Accounting Horizons, 8(2), 58-74.

Yardley, J. A. N., Kauffman, L., Cairney, T. D., \& Albrecht, D. (1992). Supplier Behavior in the U.S. Audit Market. Journal of Accounting Literature, 11(1), 151-184.

Zeff, S. A., \& Fossum, R. L. (1967). An analysis of large audit clients. Accounting Review, 42(5), 298-320.

Zimmermann, R. C. (2008). Abschlusspruefer und Bilanzpolitik der Mandanten. Wiesbaden: Gabler. 